\title{
Corrigendum: Pykälä J, Kantelinen A, Myllys L (2020) Taxonomy of Verrucaria species characterised by large spores, perithecia leaving pits in the rock and a pale thin thallus in Finland. MycoKeys 72: 43-92. https://doi.org//0.3897/mycokeys.72.56223
}

\author{
Juha Pykälä', Annina Kantelinen², Leena Myllys²
}

I Biodiversity Centre, Finnish Environment Institute, Latokartanonkaari 11, 00790, Helsinki, Finland 2 Botanical Museum, Finnish Museum of Natural History, P.O. Box 7, FI-00014, University of Helsinki, Finland

Corresponding author: Juha Pykälä ((juha.pykala@syke.fi)

Academic editor: T. Lumbsch | Received 26 April 2021 | Accepted 26 April 2021 | Published 3 June 2021

Citation: Pykälä J, Kantelinen A, Myllys L (2021) Corrigendum: Pykälä J, Kantelinen A, Myllys L (2020) Taxonomy of Verrucaria species characterised by large spores, perithecia leaving pits in the rock and a pale thin thallus in Finland. MycoKeys 72: 43-92. https://doi.org/10.3897/mycokeys.72.56223. MycoKeys 80: 163-164. https://doi.org/10.3897/ mycokeys. 80.67870

Almost all micrometres $(\mu \mathrm{m})$ have been erroneously changed into millimetres $(\mathrm{mm})$. All measurements of algal cells, ostiole, involucrellum thickness, exciple wall thickness, periphysoids, asci, ascospores and perispores should be in micrometres $(\mu \mathrm{m})$. Furthermore, thallus thickness should be in micrometres in Verrucaria bifurcata, $V$. cavernarum, $V$. difficilis and $V$. vacillans.

In the lectotypification of Verrucaria subjunctiva registration number MBT392473, MBT is missing from the MycoBank number. This note validates the lectotypification.

Verrucaria subjunctiva Nyl., Flora 67: 218, 1884

MycoBank No: 392473

Type. [RUSSIA], Sibiria Septentrionalis: Sinus Konyam ad fretum Bering, $64^{\circ} 50$ lat. bor., $173^{\circ}$ long. occid. (Greenw.) 28-30.7.1879 E. Almquist (S-L46!, lectotype, designated here); Fretum Behring, Konyam Bay, E. Almquist (H-NYL 3512!, isolectotype). 


\section{Acknowledgements}

We would like to thank Teuvo Ahti and James Lendemer for pointing out the nomenclatural issue. 